Syntax Fusion : Jurnal Nasional Indonesia

e-ISSN : 2775-4440

Vol. 1, No. 9, September 2021

\title{
PENINGKATAN MOTIVASI BELAJAR DALAM PEMBELAJARAN TEMATIK INTEGRATIF MELALUI TEKNIK REWARD PADA SISWA KELAS 1 SD NEGERI SABABILAH
}

\section{Triamerni}

SD Negeri Sababilah

Email: triamerni84@gmail.com

\begin{abstract}
Abstrak
Penelitian ini bertujuan untuk meningkatkan motivasi belajar pembelajaran mata pelajaran komprehensif pada siswa kelas I SD Negeri Sababailah Tahun Pelajaran 2019/2020 melalui teknologi reward. Subjek penelitian ini adalah siswa kelas satu SD Negeri Sababilah yang berjumlah 15 siswa. Teknik pengumpulan data melalui observasi, skala psikologis dan catatan lapangan. Analisis data yang digunakan adalah deskriptif kualitatif dan deskriptif kuantitatif. Kriteria keberhasilan penelitian tindakan ini adalah persentase skala motivasi belajar mencapai 75\%. Hasil penelitian menunjukkan bahwa penerapan reward technology dalam pembelajaran mata pelajaran komprehensif dapat meningkatkan motivasi belajar siswa kelas 1 SD Negeri Sababilah tahun pelajaran 2019/2020. Berikan reward verbal berupa pujian atas perilaku atau prestasi belajar siswa, seperti "baik, pintar, hebat". Ketika siswa menyelesaikan pekerjaan rumah mereka dengan baik dan aktif belajar, mereka akan diberikan penghargaan non-verbal berupa segel-I yang bagus dan bintang di papan juara. Dari hasil Skala Motivasi Belajar Siswa Klasik dapat diketahui persentase perolehan tindakan sebelumnya sebesar 54,31\%, persentase perolehan siklus I sebesar 71,65\%, dan persentase perolehan siklus II sebesar 90,10\%, sehingga memiliki kriteria keberhasilan. . Dari rata-rata persentase hasil skala motivasi belajar individu siswa terlihat peningkatan motivasi belajar siswa yang memenuhi kriteria keberhasilan pada pra tindakan sebanyak 4 siswa atau 8,35\% siswa, siklus I sebanyak 8 siswa atau 31,25\% siswa, dan Periode II sebanyak 15 siswa atau 93,75\% siswa.
\end{abstract}

Kata Kunci: Motivasi Belajar, Pembelajaran Tematik Integratif, Dan Teknik Reward

\section{Pendahuluan}

Pendidikan tidak dapat dipisahkan dari manusia. Menurut H.R Tilaar (2002:29), keberadaan pendidikan tidak dapat dipisahkan dari keberadaan manusia. Pendidikan dimulai sejak manusia lahir, bahkan sejak dalam kandungan, pendidikan terus berlanjut hingga akhir hayat. Melalui pendidikan, masyarakat diharapkan mampu meningkatkan 
dan mengembangkan segala potensi atau bakatnya sehingga kelak menjadi manusia yang berdaya guna dan berhasil guna (Achmad Dardiri dalam Dwi Siswoyo, 2007:1).

Hal ini sejalan dengan definisi pendidikan dalam Pasal 1 Sistem Pendidikan Nasional dalam Undang-Undang Nomor 20 Tahun 2003 Republik Indonesia yang menyatakan bahwa pendidikan adalah usaha sadar dan terencana yang bertujuan untuk menciptakan suasana belajar dan proses pembelajaran agar agar siswa dapat aktif mengembangkan kemampuannya. Memiliki potensi kekuatan spiritual keagamaan. Pengendalian diri, kepribadian, kebijaksanaan, akhlak mulia, serta keterampilan yang diperlukan bagi diri sendiri, masyarakat, dan negara.

Berdasarkan pengertian tersebut, belajar dan belajar memiliki hubungan yang erat dalam pendidikan. Menurut Hamzah B. Uno (2003: 78), belajar adalah proses bisnis yang dilakukan oleh seseorang untuk memperoleh perubahan perilaku baru, secara keseluruhan, sebagai hasil dari pengalamannya sendiri berinteraksi dengan lingkungan.

Perubahan tingkah laku manusia itu berbeda-beda, dan tidak semua perubahan tingkah laku termasuk dalam kegiatan belajar. Selain itu, Sugihartono (2007:74) menjelaskan bahwa perubahan perilaku yang terjadi dalam pembelajaran adalah perubahan yang disadari, perubahan yang terus menerus dan fungsional, perubahan yang proaktif, perubahan yang tidak sementara, dan perubahan belajar yang bertujuan atau terarah. perilaku. Perubahan perilaku yang terjadi dalam pembelajaran berkaitan dengan perubahan perilaku orang lain antara perubahan perilaku seseorang.

Menurut Aunurrahman (2010:34), kegiatan belajar mempengaruhi perolehan perubahan perilaku yang diperlukan.Pembelajaran sebagai suatu sistem dirancang untuk membantu siswa dalam proses belajar, yang meliputi serangkaian proses pembelajaran untuk mendukung dan mempengaruhi internal siswa. Guru memegang peranan penting dalam pembelajaran, karena guru harus merancang dan mempertimbangkan proses belajar siswa dengan mengamati situasi dan kondisi yang ada.

Pembelajaran harus membimbing siswa untuk mengembangkan sepenuhnya potensinya dan meningkatkan kegiatan mengajar guru, sehingga pembelajaran harus dilaksanakan sesuai dengan prinsip yang benar. Menurut prinsip belajar Dimyati dan Mujiono (2013:42) dan (1) perhatian dan motivasi, (2) semangat, (3) partisipasi langsung, (4) pengulangan, (5) tantangan, (6) umpan balik dan (7) Perbedaan Individu.

Selain prinsip belajar, faktor-faktor yang mempengaruhi kegiatan belajar dan belajar juga harus diperhatikan. Nana Syaodih (2004:162) memandang faktor-faktor tersebut dari dua sumber, yaitu dari dalam diri individu dan dari lingkungan. Faktor yang berasal dari dalam diri individu meliputi aspek fisik dan mental. Faktor fisik meliputi faktor kesehatan dan kecacatan, sedangkan faktor mental meliputi kecerdasan pribadi, sosial, psikomotor, serta status emosional dan mental. Faktor lingkungan meliputi lingkungan keluarga, lingkungan sekolah, lingkungan masyarakat dan sebagainya. Lingkungan keluarga dapat meliputi metode pendidikan orang tua, hubungan antar anggota keluarga, suasana keluarga, status ekonomi keluarga, pemahaman orang tua dan latar belakang budaya. Pada saat yang sama, lingkungan sekolah mencakup metode pengajaran, pengaturan kurikulum, hubungan guru-murid, 
hubungan siswa-siswa, disiplin sekolah, waktu mengajar dan kelas, standar kurikulum, kondisi konstruksi, metode pengajaran, pekerjaan rumah, dll. Lingkungan masyarakat yang mempengaruhi kegiatan belajar dapat berupa kegiatan siswa di masyarakat, pergaulan teman, gaya hidup sosial, dan media massa.

Pembelajaran pada kurikulum 2013 SD, baik di kelas bawah maupun atas, mengadopsi pembelajaran tematik yang komprehensif. Pembelajaran mata pelajaran yang komprehensif adalah metode pembelajaran yang mengintegrasikan berbagai kemampuan mata pelajaran yang berbeda ke dalam mata pelajaran yang berbeda (Permendikbud, 2013). Ciri-ciri pembelajaran mata pelajaran terpadu (Trianto, 2011:163-164) antara lain: (1) berpusat pada anak, (2) pengalaman langsung, (3) pemisahan yang tidak terlihat antar disiplin ilmu, (4) dari beberapa mata pelajaran Sebuah PBM disajikan dalam mata pelajaran, (5) bersifat fleksibel, dan (6) hasil belajar dapat dikembangkan sesuai dengan minat dan kebutuhan anak.

Dalam kegiatan belajar dan belajar hendaknya kita memperhatikan faktor-faktor yang mempengaruhi kegiatan belajar dan karakteristik pembelajaran yang digunakan. Jika ini tidak diperhatikan, maka akan ada masalah belajar. Seperti yang dialami dalam pembelajaran mata pelajaran komprehensif tahun pertama SDN Sababilah, tema yang diangkat adalah subtema "diriku" dan "Aku Istimewa". Menurut hasil observasi peneliti pada hari Jumat, 10 Januari 2020 sampai dengan Selasa, 14 Maret 2020, permasalahan (selama proses pembelajaran) adalah sebagai berikut: Pertama, kurangnya semangat belajar menyebabkan kurangnya semangat belajar siswa. Wawasan dari guru. Sinestesia digunakan untuk memberikan gambaran kepada siswa tentang apa yang akan dipelajari atau diperdalam dalam studi mereka. Saat kelas dimulai, guru tidak memberikan firasat kepada siswa, tetapi langsung mengajak siswa untuk membaca bersama tentang Aku Istimewa. Akibatnya perhatian siswa tidak begitu terfokus pada pembelajaran yang akan dilakukan, dan minat belajar siswa menjadi berkurang.

Kedua, metode mengajar masih mendominasi kegiatan mengajar guru. Metode pengajaran adalah karakteristik kapur. Menurut Kemp (Wina Sanjaya, 2011: 94), strategi pembelajaran adalah kegiatan belajar yang harus diselesaikan guru dan siswa secara bersama-sama untuk mencapai tujuan pembelajaran secara efektif dan efisien. Metode adalah cara yang dapat digunakan untuk melaksanakan strategi yang telah ditetapkan. Dalam menentukan strategi yang akan ditempuh, guru harus cermat memilih dan menentukan metode yang sesuai dengan karakteristik siswa. Strategi kapur dan percakapan menekankan proses dimana guru memberikan materi kepada siswa secara lisan. Strategi ini berorientasi pada guru (teacher centered), sehingga peran guru sangat menonjol. Akibatnya siswa cenderung duduk pasif dan mendengarkan guru. Hal ini tidak sejalan dengan karakteristik pembelajaran mata pelajaran komprehensif yang berpusat pada siswa.

Ketiga, kurangnya media pembelajaran yang digunakan oleh guru. Dalam kegiatan pembelajaran, guru yang memimpin jalannya perkuliahan tidak mendapatkan dukungan media pembelajaran yang menarik minat siswa. Tujuan media adalah untuk membantu siswa mentransfer pembelajaran yang diberikan oleh guru. Menurut teori 
Piaget (dalam Sugihartono, 2007: 109), siswa sekolah dasar (7-11 tahun) termasuk dalam tahap komputasi spesifik. Jika ada benda konkret atau benda setengah beton yang dapat membuat siswa memahami pelajaran tersebut, maka anak akan lebih mudah memahaminya. Media yang digunakan guru kurang memadai, terlihat di kelas guru hanya menggunakan buku topik yang dimiliki masing-masing siswa..

Keempat, siswa kurang perhatian dalam belajar. Perhatian siswa terhadap pembelajaran akan membantu untuk menerima materi yang diberikan oleh guru. Oleh karena itu, perhatian siswa merupakan hal penting yang diperlukan untuk pembelajaran yang efektif. Dari beberapa siswa bermain pesawat kertas, berbicara dengan teman lain tentang hal-hal yang tidak berhubungan dengan pembelajaran, bermain dengan pensil dan berbaring di bangku, terlihat siswa kurang memperhatikan pembelajaran.

Kelima, kondisi kelas yang tidak kondusif. Menurut Dimyati dan Mujiono (2013:169), ukuran tiap kelas umumnya antara 10-45. SD Negeri Sababilah memiliki 15 siswa di kelas satu. Jumlah ini termasuk jumlah standar. Jumlah siswa sebanyak 15 siswa, satu guru membantu pembelajaran, dan guru tidak dapat membagi perhatian secara merata kepada semua siswa. Akibatnya, kondisi kelas menjadi kurang kondusif dan pembelajaran menjadi kurang efektif.

Keenam, siswa kurang motivasi dalam kegiatan belajar. Hamzah B. Uno (2013: 3) menggambarkan motivasi belajar sebagai dorongan internal dan eksternal kepada siswa yang sedang belajar untuk memperbaiki perilakunya, biasanya dengan beberapa indikator atau unsur pendukung.

Motivasi belajar sangat penting, karena memiliki motivasi berarti siswa memiliki keinginan untuk memahami topik. Pada permasalahan kurangnya motivasi siswa untuk mengikuti pembelajaran, terlihat bahwa guru meminta salah satu siswa untuk menyebutkan buah kesukaannya. Namun, tidak ada siswa yang mau datang ke kelas dan menceritakan buah kesukaannya. Guru juga tidak menindaklanjuti, hanya melewatkannya, dan terus menugaskan siswa untuk mengerjakan soal. Sehingga apa yang diberikan guru tidak mendapat umpan balik dari siswa.

Dari beberapa permasalahan yang muncul dalam pembelajaran tema komprehensif subtema "Aku sendiri" dan "Aku Istimewa" di kelas I SD Negeri Sababilah, peneliti memfokuskan pada permasalahan kurangnya motivasi belajar siswa. Karena motivasi memegang peranan penting dalam belajar dan belajar. Pada dasarnya motivasi dapat membantu memahami dan menjelaskan perilaku individu yang sedang belajar. Menurut Hamzah B. Uno (2013:27), peran penting motivasi dalam belajar dan pembelajaran meliputi (1) mengidentifikasi hal-hal yang dapat dijadikan sebagai penguat belajar, (2) memperjelas tujuan pembelajaran yang ingin dicapai, dan (3) menentukan desakan belajar.

\section{Metode Penelitian}

Penelitian ini mengadopsi jenis Penelitian Tindakan Kelas. Modus pelaksanaan penelitian tindakan kelas ini dilakukan melalui modus kolaboratif. Dalam model ini, inisiatif untuk melakukan PTK biasanya tidak datang dari guru, tetapi dari pihak luar yang 
ingin memecahkan masalah pembelajaran (Wina Sanjaya, 2009: 59). Peran guru adalah sebagai anggota tim peneliti, sebagai pelaksana tindakan yang dirancang oleh tim peneliti, dan peneliti sebagai pengamat. Guru bermaksud untuk meningkatkan motivasi belajar pembelajaran topik yang komprehensif dengan menggunakan teknologi reward dalam pembelajaran mereka.

Desain penelitian tindakan kelas ini menggunakan model spiral Kemmis dan Taggart yang tersusun dari perulangan. Model spiral ini dikembangkan oleh Stephen Kemmis dan Robin Taggart. Penelitian ini dilakukan dalam beberapa siklus, dan setiap siklus terdiri dari beberapa tahapan, yaitu: perencanaan, tindakan dan observasi, dan refleksi (Suharsimi Arikunto, 2006: 93).

Setiap siklus dilaksanakan dalam beberapa kegiatan pembelajaran. Siklus I merupakan dasar penentuan dan pengembangan siklus II. Siklus II merupakan perbaikan dari siklus I untuk meningkatkan kualitas pembelajaran. Pada akhir kegiatan pembelajaran putaran pertama, guru kelas sebagai kolaborator untuk mengevaluasi dan melakukan refleksi untuk mengetahui efektivitas pembelajaran dan kemungkinan hambatan. Keputusan untuk menghentikan atau melanjutkan pengulangan adalah keputusan bersama antara peneliti dan guru kelas. Jika peneliti dan kepala sekolah setuju bahwa penggunaan teknik reward dalam proses pembelajaran meningkatkan motivasi siswa dalam pembelajaran topik yang komprehensif, stop loop.

\section{Hasil Dan Pembahasan}

Penelitian Tindakan Kelas ini dilakukan di SD Negeri Sababilah yang beralamat di Jalan Soekarno - Hatta Desa Sababilah. Lokasi sekolah ini tidak jauh dari jalan raya. Sekolah ini didirikan pada tahun 2003. Luas SD Negeri Sababilah yaitu 2.477 $\mathrm{m}^{2}$. Secara keseluruhan kondisi fisik sekolah dalam keadaan baik. Sekolah ini memiliki 6 ruang kelas, ruangan lain yang ada yaitu ruang guru/ ruang kepala sekolah, perpustakaan, ruang UKS, dapur, dan toilet. Saat ini SD Negeri Sababilah dipimpin oleh Yustina Juana SP.d SD.

Subjek penelitian ini adalah siswa kelas 1 SD Negeri Sababilah yang berjumlah 15 siswa, terdiri dari 11 siswa perempuan dan 4 siswa laki-laki.

\section{1) Implementasi Tindakan Siklus 1}

Kegiatan siklus pertama meliputi kegiatan perencanaan, tindakan, observasi dan refleksi. Masing-masing kegiatan tersebut dijabarkan sebagai berikut:

\section{a) Perencanaan siklus 1}

(1) Menentukan skenario pembelajaran menggunakan teknik reward pada pembelajaran tematik integratif. Skenario pembelajaran yang telah disepakati bersama guru dituangkan dalam Rencana Pelaksanaan Pembelajaran (RPP) yang kemudian diserahkan kepada guru untuk menjadi pedoman selama melaksanakan kegiatan pembelajaran. Pada siklus 1 tema yang digunakan adalah tema Benda, Hewan dan Tanaman di Sekitarku, dengan subtema Hewan di Sekitarku. 
(2) Menentukan dan menyiapkan teknik reward yang akan digunakan dalam pembelajaran.

(3) Mempersiapkan lembar observasi dan skala motivasi belajar siswa pada pembelajaran tematik integratif. Lembar observasi meliputi lembar observasi siswa dan guru yang diisi oleh peneliti bersama rekan sejawat.

\section{b) Tindakan siklus 1}

Melakukan KBM sesuai dengan RPP yang telah di buat sebanyak 2 (dua) kali pertemuan

\section{c) Observasi siklus 1}

Selama fase tindakan, peneliti juga melakukan observasi. Peneliti melakukan observasi langsung dengan menggunakan tabel observasi yang telah disiapkan. Selama tahap observasi, peneliti dibantu oleh seorang guru dari SD N Sababilah. Mengamati aktivitas siswa dalam proses pembelajaran yang berkaitan dengan motivasi belajar, dan aktivitas guru saat menggunakan teknologi reward untuk memberikan materi pembelajaran tematik yang komprehensif. Adapun rincian hasil observasi siklus I adalah sebagai berikut:

Berdasarkan hasil observasi aktivitas siswa putaran pertama pada pertemuan pertama, rata-rata aktivitas siswa secara klasikal dalam kategori sedang adalah 69,15\%. (Lihat halaman 185 di Lampiran 4.3). Hasil tersebut mengalami peningkatan dibandingkan hasil sebelum tindakan, meskipun hasil tersebut termasuk dalam kategori sedang dan tidak memenuhi kriteria keberhasilan. Hasil observasi aktivitas siswa pada siklus I pertemuan I secara klasikal tercantum pada Tabel 10, sebagai berikut:

Tabel 10. Hasil Observasi Aktivitas Siswa secara Klasikal pada Siklus I Pertemuan 1

\begin{tabular}{|c|c|c|c|c|c|}
\hline \multirow[b]{2}{*}{ Indikator } & Skor & Skor & Persentase & \multirow[b]{2}{*}{ Kategori } & \multirow[b]{2}{*}{ Keterangan } \\
\hline & Total & Perolehan & $(\%)$ & & \\
\hline mandiri dalam & 192 & 133.6 & 69.58 & sedang & Belum \\
\hline belajar & & & & & Tercapai \\
\hline ulet meghadapi & 192 & 138.83 & 72.30 & sedang & belum \\
\hline kesulitan & & & & & tercapai \\
\hline $\begin{array}{c}\text { dapat } \\
\text { mempertahankan } \\
\text { pendapatnya }\end{array}$ & 192 & 129.75 & 67.57 & sedang & $\begin{array}{c}\text { belum } \\
\text { Tercapai }\end{array}$ \\
\hline $\begin{array}{c}\text { adanya } \\
\text { penghargaan } \\
\text { dalam belajar }\end{array}$ & 192 & 133.2 & 69.37 & sedang & $\begin{array}{c}\text { Belum } \\
\text { Tercapai }\end{array}$ \\
\hline
\end{tabular}




\begin{tabular}{|c|c|c|c|c|c|}
\hline adanya kegiatan & & & & & Belum \\
\hline $\begin{array}{l}\text { yang menarik } \\
\text { dalam belajar }\end{array}$ & 192 & 133.83 & 69.70 & sedang & Tercapai \\
\hline $\begin{array}{c}\text { adanya } \\
\text { lingkungan }\end{array}$ & 192 & 127.5 & 66.40 & Sedang & Belum \\
\hline $\begin{array}{c}\text { belajar yang } \\
\text { kondusif }\end{array}$ & & & & & Tercapai \\
\hline Rata-rata & 1152 & 796.71 & 69.15 & sedang & $\begin{array}{c}\text { Belum } \\
\text { Tercapai }\end{array}$ \\
\hline
\end{tabular}

Pada pertemuan II siklus I, hasil observasi aktivitas siswa secara klasikal ratarata 72,15\% dengan kategori sedang. (Lihat halaman 188 di Lampiran 4.5). Hasil tersebut mengalami peningkatan dibandingkan dengan hasil siklus I pertemuan pertama, meskipun hasil tersebut termasuk dalam kategori sedang dan belum mencapai kriteria keberhasilan. Hasil observasi aktivitas siswa putaran pertama pada pertemuan kedua ditunjukkan pada Tabel 11.

Tabel 11. Hasil Observasi Aktivitas Siswa secara Klasikal pada Siklus I Pertemuan 2

\begin{tabular}{cccccc}
\hline Indikator & Skor & Skor & Persentase & Kategori & Keterangan \\
& Total & Perolehan & $(\boldsymbol{\%})$ & & Belum \\
\hline $\begin{array}{c}\text { mandiri dalam } \\
\text { belajar }\end{array}$ & 192 & 140.8 & 73.33 & sedang & Tercapai \\
\hline $\begin{array}{c}\text { ulet meghadapi } \\
\text { kesulitan }\end{array}$ & 192 & 142.1 & 74.04 & rendah & Belum \\
$\begin{array}{c}\text { dapat } \\
\text { mempertahankan }\end{array}$ & 192 & 138 & 71.87 & rendah & Bercapai \\
$\begin{array}{c}\text { pendapatnya } \\
\text { adanya }\end{array}$ & & & & Tercapai \\
\hline $\begin{array}{c}\text { penghargaan } \\
\text { dalam belajar }\end{array}$ & 192 & 137.2 & 71.45 & sedang & Belum \\
\hline adanya kegiatan & & & & Tercapai \\
\hline
\end{tabular}


Triamerni

\begin{tabular}{cccccc}
$\begin{array}{c}\text { yang menarik } \\
\text { dalam belajar }\end{array}$ & 192 & 136.5 & 71.09 & Sedang & Tercapai \\
\hline $\begin{array}{c}\text { adanya } \\
\text { lingkungan } \\
\begin{array}{c}\text { belajar yang } \\
\text { kondusif }\end{array}\end{array}$ & 192 & 136.25 & 70.96 & sedang & Belum \\
\hline Rata-rata & $\mathbf{1 1 5 2}$ & $\mathbf{8 3 0 . 9 1}$ & $\mathbf{7 2 . 1 2}$ & sedang & Bercapai \\
\hline
\end{tabular}

Seperti dapat dilihat dari tabel di atas, rata-rata persentase aktivitas siswa klasikal pada siklus I pertemuan I adalah $69,15 \%$, dan rata-rata persentase aktivitas siswa pada siklus I pertemuan II adalah $72,12 \%$. Hasil yang diperoleh pada siklus I dan II pertemuan pertama dan kedua mengalami peningkatan dibandingkan dengan hasil yang diperoleh pada pra tindakan.

Secara individual, 4 dari 15 siswa atau 31,25\% skala motivasi belajar siswa siklus I termasuk dalam kategori tinggi. Sebanyak 6 siswa atau 64,58\% berada pada kategori sedang, dan 5 siswa atau 4,17\% masih dalam kategori rendah (lihat Lampiran 4.20, halaman 212). Hasil skala motivasi belajar individu siswa pada Siklus I dapat dilihat pada Tabel 15, seperti terlihat di bawah ini. Tabel 15. Hasil Skala Motivasi Belajar Individu Siswa Periode I

\begin{tabular}{ccc}
\hline & \multicolumn{2}{c}{ siklus I } \\
\cline { 2 - 3 } Kategori & jumlah & $\%$ \\
\hline Tinggi & 4 & 31.25 \\
\hline Sedang & 6 & 64.58 \\
\hline Rendah & & \\
\hline
\end{tabular}

Sedangkan secara individu, skala motivasi belajar siswa pada siklus II sejumlah 12 siswa dari 15 siswa atau $93.75 \%$ termasuk dalam kategori tinggi. Sejumlah 3 siswa atau $6.25 \%$ termasuk dalam kategori sedang (lihat Lampiran 4.22 halaman 215). Hasil dari skala motivasi belajar siswa pada siklus II secara individu disajikan dalam tabel 22 sebagai berikut.

Tabel 22. Hasil skala motivasi belajar siswa secara individu pada siklus II

\begin{tabular}{ll}
\hline & siklus \\
Kategori & II \\
\hline
\end{tabular}




\begin{tabular}{ccc} 
& Jumlah & $\%$ \\
\hline Tinggi & 12 & 93.75 \\
\hline Sedang & 3 & 6.25 \\
\hline Rendah & 0 & 0 \\
\hline
\end{tabular}

Pada tahap pra tindakan, sebanyak 4 dari 7 indikator masih berstandar rendah, yaitu kemandirian belajar, kemampuan mempertahankan pendapat sendiri, kegiatan menarik dalam belajar, dan indikator lingkungan kondusif untuk belajar. Sedangkan tiga indikator lainnya tergolong standar sedang, yaitu ketekunan menghadapi kesulitan, harapan dan keinginan untuk masa depan, dan apresiasi belajar.

Pada siklus I, ketercapaian ketiga indikator motivasi belajar siswa menunjukkan pertumbuhan. Indikator yang dicapai adalah harapan dan cita-cita, apresiasi belajar, dan apresiasi belajar. Pada tahap pra tindakan, indikator-indikator tersebut belum tercapai. Dari 7 indikator tersebut, 4 indikator belum tercapai. Indikator yang belum terpenuhi adalah kemandirian belajar, ulet dalam menghadapi kesulitan, kemampuan mempertahankan pendapat, dan aktivitas pembelajaran yang menarik. Pada siklus II, tujuh indikator termasuk dalam kategori tinggi. Jadikan indikator-indikator tersebut memenuhi kriteria keberhasilan tindakan. Hal ini menunjukkan bahwa dari hasil pra tindakan, siklus I dan siklus II skala motivasi belajar siswa mengalami peningkatan.

Pada siklus I jumlah siswa yang memperoleh persentase skala motivasi belajar yang termasuk dalam kategori tinggi mengalami peningkatan yaitu sebanyak 10 siswa atau $31,25 \%$ siswa. Siswa yang memperoleh persentase tertentu dari skala motivasi belajar tergolong dalam kategori sedang yaitu sebanyak 8 siswa atau 64,58\% siswa. Sisanya 2 siswa atau $4,17 \%$ termasuk dalam kategori rendah.

Siklus II juga mengalami peningkatan, terlihat dari jumlah siswa yang memperoleh persentase skala motivasi belajar yang termasuk dalam kategori tinggi, yaitu sebanyak 15 siswa atau 93,75\% siswa. Sebanyak 3 siswa atau 6,25\% siswa berada pada kategori sedang, siswa dalam kategori rendah, tidak ada atau 0\%. Secara keseluruhan hasil skala motivasi dari pra tindakan ke siklus I dan dari siklus I ke siklus II mengalami peningkatan.

Keberhasilan penggunaan teknologi reward untuk meningkatkan motivasi belajar siswa pada pembelajaran topik komprehensif didasarkan pada hasil skala motivasi belajar siswa. Berdasarkan rangkuman motivasi belajar siswa dan skala aktivitas belajar siswa dalam penelitian ini, dari tindakan sebelumnya siklus I dan siklus II meningkat. Dilihat dari hasil penelitian ini, pembelajaran mata pelajaran yang komprehensif melalui teknologi reward dapat meningkatkan motivasi belajar siswa dan aktivitas siswa yang berkaitan dengan motivasi belajar. Hal ini terlihat dari motivasi dan semangat belajar siswa yang setiap siklusnya meningkat hingga siklus II mencapai kriteria keberhasilan yaitu 75\%. Bagi siswa yang tidak memenuhi kriteria keberhasilan akan ditangani oleh guru. Namun, seperti yang dihipotesiskan penelitian ini, 
penggunaan teknik reward dalam pembelajaran mata pelajaran komprehensif dapat meningkatkan motivasi belajar siswa SD Sababilah.

\section{Kesimpulan}

Berdasarkan hasil penelitian tindakan kelas siswa SD N Sababilah kelas satu yang menggunakan teknologi reward untuk pembelajaran mata pelajaran yang komprehensif, dapat disimpulkan bahwa teknologi reward dapat meningkatkan motivasi belajar siswa kelas satu SD N Sababilah. Teknologi reward yang digunakan dalam pembelajaran adalah reward verbal dan non-verbal reward. Berikan reward verbal berupa pujian atas perilaku atau prestasi belajar siswa, seperti "baik, pintar, hebat". Ketika siswa menyelesaikan pekerjaan rumah mereka dengan baik dan aktif belajar, mereka akan diberikan penghargaan non-verbal berupa segel-I yang bagus dan bintang di papan juara. Guru merancang pembelajaran sesuai dengan karakteristik tema pembelajaran yang komprehensif, dan menggunakan keterampilan reward untuk membuat siswa lebih aktif dalam belajar. Sesuai dengan kegiatan dalam pembelajaran tema komprehensif, penerapan teknologi reward dilakukan secara kelompok dan individu. Teknologi reward diterapkan secara merata di dalam kelas, agar tidak menimbulkan kecemburuan di kalangan siswa, dan semua siswa berpeluang untuk mendapatkan reward.

Hal ini dapat dilihat dari hasil Skala Motivasi Belajar Siswa Klasik bahwa motivasi belajar mengalami peningkatan, Pra tindakan sebesar 54,31\%, siklus I sebesar $71,65 \%$, dan siklus II sebesar 90,10\%, sehingga telah mencapai standar keberhasilan. Dari rata-rata persentase hasil skala motivasi belajar individu siswa terlihat adanya peningkatan motivasi belajar siswa yang memenuhi kriteria keberhasilan pada pra tindakan adalah 3 siswa atau 8,35\% siswa, siklus I sebanyak 15 siswa atau 31,25 siswa. $\%$ siswa, dan Periode II sebanyak 15 siswa atau 93,75\% siswa. 
Peningkatan Motivasi Belajar Dalam Pembelajaran Tematik Integratif Melalui Teknik Reward

\section{Bibliografi}

Ainurrahman. (2010). Belajar dan Pembelajaran. Bandung: Alfabeta.

Dimyanti dan Mujiono. (2013). Belajar dan Pembelajaran. Jakarta: Rineka Cipta.

Dwi Siswoyo. (2007). Ilmu Pendidikan. Yogyakarta: UNY Press.

Ellis Ormrod, Jeanne. (2008). Psikologi Pendidikan (Alih bahasa: Dra. Wahyu Indianti, M. Si., dkk). Jakarta: Erlangga.

Hamzah B. Uno. (2013). Teori Motivasi dan Pengukurannya. Gorontalo: Bumi Aksara.

H. A. R Tilaar. (2002). Pendidikan, Kebudayaan dan Masyarakat Madani Indonesia. Bandung: Rosdakarya.

John M. Echols. (2003). Kamus Bahasa Inggris-Indonesia. Jakarta: PT. Gramedia Pustaka Indonesia

Kemendikbud. (2003). Undang-Undang RI Nomor 20 Tahun 2003 tentang Sistem Pendidikan Nasional. Bandung: Citra Umbara.

Muhibbin Syah. (2008). Psikologi Pendidikan. Jakarta: Rosdakarya.

Nana Syaodih Sukadinata. (2004). Landasan Psikologi Proses Pendidikan. Bandung: Remaja Rosdakarya.

Ngalim Purwanto. (2002). Ilmu Pendidikan Teori dan Praktis. Bandung: Rosdakarya.

Oemar Hamalik. (2008). Proses Belajar Mengajar. Jakarta: Bumi Aksara.

Rian Putri Hapsari. (2013). Studi Tentang Pelaksanaan Pemberian Reward Dalam Meningkatkan Motivasi Belajar Kelompok A di TK Islam Al Azhar 35 Surabaya. Jurnal Penelitian. Universitas Negeri Surabaya.

Riduwan. (2011). Belajar Mudah Penelitian. Bandung: Alfabeta.

Rita Eka Izzaty. (2008). Perkembangan Peserta Didik. Yogyakarta: UNY Press.

Rochiati Wiriaatmaja. (2006). Penelitian Tindakan Kelas. Bandung: Rosdakarya.

Saifudin Azwar. (2013). Penyusunan Skala Psikologi.Yogyakarta: Pustaka Pelajar. 
Triamerni

Saiful Bahri Djamarah. (2005). Guru dan Anak Didik. Bandung: Alfabeta.

Santrock. J. W. (2010). Psikologi Pendidikan. Jakarta: Bumi Aksara.

Sardiman A. M. (2012). Interaksi dan Motivasi Belajar Mengajar edisi revisi. Jakarta: Rajawali.

Sudjana. (2001). Metode dan Teknik Pembelajaran Partisipatif. Bandung: Falah Production.

Sugihartono, dkk. (2007). Psikologi Pendidikan. Yogyakarta: UNY Press.

Sugiyono. (2009). Metode Penelitian Pendidikan. Bandung: Alfabeta.

Suharsimi Arikunto. (2006). Prosedur Penelitian Suatu Pendekatan Praktik. Jakarta:Rineka Cipta.

Sumardi Suryabrata. (2006). Psikologi Pendidikan. Jakarta: Raja Grafindo Persada.

Trianto. (2011). Desain Pengembangan Pembelajaran Tematik bagi Anak Usia Dini TK/ RA dan Anak Usia Kelas Awal SD/MI. Jakarta: Kencana.

User Usman. (2006). Menjadi Guru Profesional. Bandung: Rosdakarya. 